\title{
New Priorities for Dairy Cows Feed Production System Using Fuzzy-AHP
}

\author{
Puspa Ayu Indah Prameswari ${ }^{\mathrm{a} 1}$, Sukardi $^{\mathrm{a} 2}$, Sri Kumalaningsih ${ }^{\mathrm{a} 3}$ \\ ${ }^{a}$ Department of Agroindustrial Technology, Brawijaya University \\ Malang, East Java - 65145, Indonesia \\ puspaprameswari@yahoo.com
}

\begin{abstract}
Management criteria can be used as the deciding device of the performance of dairy cows feed production system successfulness by prioritizing those criteria, and it can be used as an improvement step. The aim of this study was to determine the priority of management criteria and established the improvement step to increase the performances of the dairy cows feed production system in Batu, East Java by prioritizing four management criteria (Planning, Organizing, Directing, and Controlling). The method used the Fuzzy Analytic Hierarchy Process (Fuzzy-AHP) which is a combination of two methods, Analytic Hierarchy Process (AHP) and fuzzy logic. Fuzzy AHP is proposing an evaluation tool which inherits advantages from that two methods. Fuzzy AHP will translate decisions makers comparison judgment into the fuzzy number. There were three highest priorities for management criteria, namely goal planning for the long-term from planning criteria, divisions of work from organizing criteria, and activator from controlling criteria. It was concluded that those three highest management criteria could be established as an improvement step for the performances of dairy cows feed production system.
\end{abstract}

Keywords: Feed, Fuzzy AHP, Management Criteria, Production, Production System

\section{Introduction}

Batu region is located in East Java and dedicated mainly to milk production with approximately $22,672,637$ kilograms [1] . One of the most important effort to control the consistency of these milk production is completing dairy needs [2]. It would be completed with controlling animal feed. But, a higher amount of dairy cows feed makes higher production cost. The best solution for this problem is using agriculture waste from corn for producing dairy cows feed. Corn forage mostly used as forage type fed to cows for over ten years and it provides high-energy content [3].Statistic Indonesia [4] reported that average agriculture production, especially for corn are 2,6796 tons to the $2013-2015$ season.

Study about management approach of dairy cows feeds production system should be conducted to determine the prioritized criteria to build an effective strategy. The difference between the successful result of dairy cows production system caused by different management approach [5]. Managing production includes of Planning, Organizing, Directing, and Controlling. Planning defines a management aspect that related to decisions making which has to do and how to do that Organizing indicates the functions of management that includes an organizational structure and allocate human resource for completing the goals [6]. Directing will determine directly related to the performances. Controlling are used to evaluate the result [5].

To build an effective strategy for dairy cows feed production system, it needed a method that can prioritize management criteria. The methods used to prioritize management criteria are Fuzzy AHP, which is the combination of fuzzy logic and Analytic Hierarchy Process [7]. Fuzzy AHP is the development of AHP where traditional AHP still hard to exactly show decision maker's judgement in alternative comparison [8]. The used of Fuzzy AHP describe better the unclear decisions than AHP. Fuzzy AHP is considered more confident to decision makers because it gives an interval of judgement than constant judgment and ability to handle the imprecision information [9]. The study about Fuzzy AHP has been done in many sectors such 
plant evaluation method [10], optimization of decision-making system [11], evaluation private institution technique [7], planning new management approach for milk production [12].

The objective of this study was to determine the priority criteria of management to build the best strategy for increasing performances of dairy cows feed production system in Batu, East Java. Research conducted in Batu City, East Java which is well known as a milk producer area in East Java and because of its good potentials supported by feed sources availability and human resources availability.

\section{Methods}

Research conducted in Batu City, East Java in particular group of dairy cows feed production system in 2017. The data used in this research were collected through the application of the questionnaire in the management sector with 16 sub-subcriteria as shown in Table 1. To collect information, direct interviews and existing document have been used. Direct interviews were conducted with the expert in the organization for determining variables of management criteria and it was supported by existing document. Fuzzy AHP is used to prioritize management criteria based on expert opinion. The methodology for the present study can be seen in Figure 1.

Table 1. The Variables of Management Criteria

\begin{tabular}{|c|c|c|}
\hline Criteria & Subcriteria & Sub-subcriteria \\
\hline \multirow[t]{4}{*}{ Planning } & Goal Planning & Long Term \\
\hline & & Short Term \\
\hline & Process Planning & Long Term \\
\hline & & Short Term \\
\hline \multirow[t]{4}{*}{ Organizing } & $\begin{array}{l}\text { Organisational } \\
\text { Structure }\end{array}$ & Determine The Relation In Organization \\
\hline & & Coordination \\
\hline & Work Placement & Divisions Of Work \\
\hline & & Grouping Work \\
\hline \multirow[t]{4}{*}{ Directing } & $\begin{array}{l}\text { Managing Human } \\
\text { Resources }\end{array}$ & Training \\
\hline & & Training Frequency \\
\hline & Give Task & Give Commands \\
\hline & & Delegation Of Authority \\
\hline \multirow[t]{4}{*}{ Controlling } & Goal Evaluation & Process Control \\
\hline & & Performance Control \\
\hline & Corrective Action & Comparator \\
\hline & & Activator \\
\hline
\end{tabular}




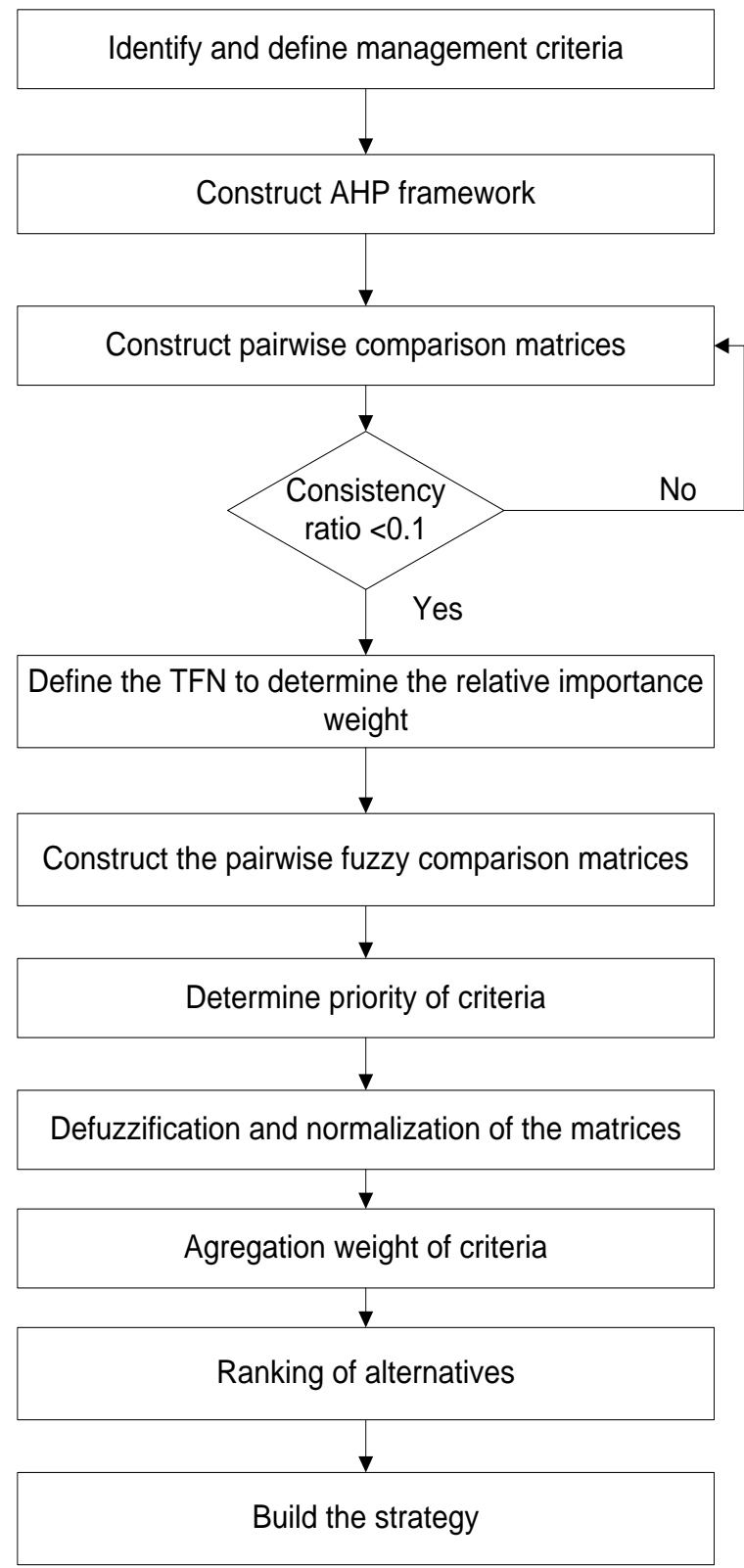

Figure 1. Flowchart of The Study

The step of Fuzzy AHP methodology is as follows:

1. Develop a hierarchical structure; the first step is to break-down the complex problem into a hierarchical structure as illustrated in Figure 2.

2. Determine pairwise comparison matrices; pairwise comparisons are needed to show the condition of each criterion in a quantitative data. The pairwise comparisons of AHP shown in Table 2.

3. Determine vector of priority

4. Determine consistency index, to check the consistency; we should calculate $\lambda_{\max }$ (maximum eigenvalue of the pairwise comparison matrix) is calculated using Eq. (1)

$$
\begin{aligned}
& \lambda \max =\frac{1}{n} \sum_{i=1}^{n} W \\
& C I=\frac{\lambda \max -n}{n-1}
\end{aligned}
$$


Tabel 2. The AHP Pairwise Comparison Scale [13]

\begin{tabular}{cccc}
$\begin{array}{c}\text { Numerical } \\
\text { rating }\end{array}$ & Linguistic scale & Description & $\begin{array}{c}\text { Triangular } \\
\text { fuzzy scale }\end{array}$ \\
\hline 1 & Equal important & Both elements are equally important & $(1,1,3)$ \\
3 & Moderately important & $\begin{array}{c}\text { An element is moderately important } \\
\text { than other }\end{array}$ & $(1,3,5)$ \\
5 & Strongly important & An element is strongly important than & other \\
7 & $\begin{array}{c}\text { Very strongly } \\
\text { important }\end{array}$ & $\begin{array}{c}\text { An element is very strongly important } \\
\text { than other }\end{array}$ & $(3,5,7)$ \\
9 & Extremely important & An element is extremely important & $(5,7,9)$ \\
than other & $(7,9,9)$ \\
\hline
\end{tabular}

5. Consistency ratio check. Consistency ratio is calculated using Eq. (3)

$$
C R=\frac{C I}{R I}
$$

Where CR is Consistency Ratio, $\mathrm{Cl}$ is Consistency Index, and $\mathrm{RI}$ is Random Index. The $C R$ value should be less than 0.1 which means the value is consistent and acceptable.

6. Developing pairwise fuzzy comparison matrices. TFN is used to construct the fuzzy judgment which represents the preferences of the decision maker.

The triangular type fuzzy membership function is shown in Eq. (4).

$$
\left\{\begin{array}{c}
0, x<1 \\
\frac{x-1}{m-1}, l \leq x \leq m \\
\frac{u-x}{u-m}, m \leq x \leq u \\
0, x>u
\end{array}\right.
$$

7. Value of $\sum_{j=1}^{m} \boldsymbol{M}_{i}^{j}=\sum_{j=1}^{m} \boldsymbol{l} \boldsymbol{j}, \sum_{j=1}^{m} \boldsymbol{m} \boldsymbol{j}, \sum_{j=1}^{m} \boldsymbol{u} \boldsymbol{j}$ are calculated based on sum of each row of number TFN members

8. Value of $\sum_{i=1}^{\mathrm{n}} \sum_{j=1}^{\mathrm{m}} \boldsymbol{M}_{g i}^{j}$ is the sum of all TFN members in pairwise comparison matrix.

9. Determining value of Fuzzy Syntethic Extents

$$
\begin{gathered}
S i=\sum_{j=1}^{m} M_{i}^{j} x \frac{1}{\sum_{i=1}^{n} \sum_{j=1}^{m} M_{i}^{j}} \text { Where: } \\
\frac{1}{\sum_{i=1}^{n} \sum_{j=1}^{m} M_{i}^{j}}=\frac{1}{\sum_{i=1}^{n} u i, \sum_{j=1}^{n} m i, \sum_{i=1}^{n} l i}
\end{gathered}
$$

Where: $M$ is an object (criteria dan subcriteria), $i$ is an index number of rows, $j$ is an index number of columns. I is a lower value, $\mathrm{m}$ is medium value, and $u$ is an upper value

10. Determining value of degree of possibility. The degree of probability of $M_{2} \geq M_{1}$ $\left(M_{2}=\left(l_{2}, m_{2}, u_{2}\right)\right.$ and $\left.M_{2}=\left(l_{1}, m_{1}, u_{1}\right)\right)$ define as follows: $V\left(M_{2} \geq M_{1}\right)=\operatorname{sub}\left[\min \left(\mu_{m 1}(x), \mu_{m 2}(y)\right.\right.$ )] $\mathrm{y} \geq \mathrm{x}$, and can be written as follows

$V\left(M_{2} \geq M_{1}\right)=$ hgt $\left(M_{1} \cap M_{2}\right) \mu_{m 2}(d)$

Where 1 , if $m_{2} \geq m_{1} ; 0$, if $I_{1} \geq u_{2}$, moreover $\frac{l 1-u 2}{(m 2-u 2)-(m 1-l 1)}$

11.

$$
\text { Determining value of degree of probability }
$$

If fuzzy number is greater than $\mathrm{k}$, for $\mathrm{Mi},(i=1,2, . ., \mathrm{k})$ can be define as follows:

$\mathrm{V}\left(\mathrm{M} \geq \mathrm{M}_{1}, \mathrm{M}_{2}, \ldots, \mathrm{Mk}\right)=\mathrm{V}\left(\mathrm{M} \geq \mathrm{M}_{1}\right)$ and $\mathrm{X}\left(\mathrm{M} \geq \mathrm{M}_{2}\right)$ and 
LONTAR KOMPUTER VOL. 9, NO. 3 DECEMBER 2018

DOI : 10.24843/LKJITI.2018.v09.i03.p03

Accredited B by RISTEKDIKTI Decree No. 51/E/KPT/2017

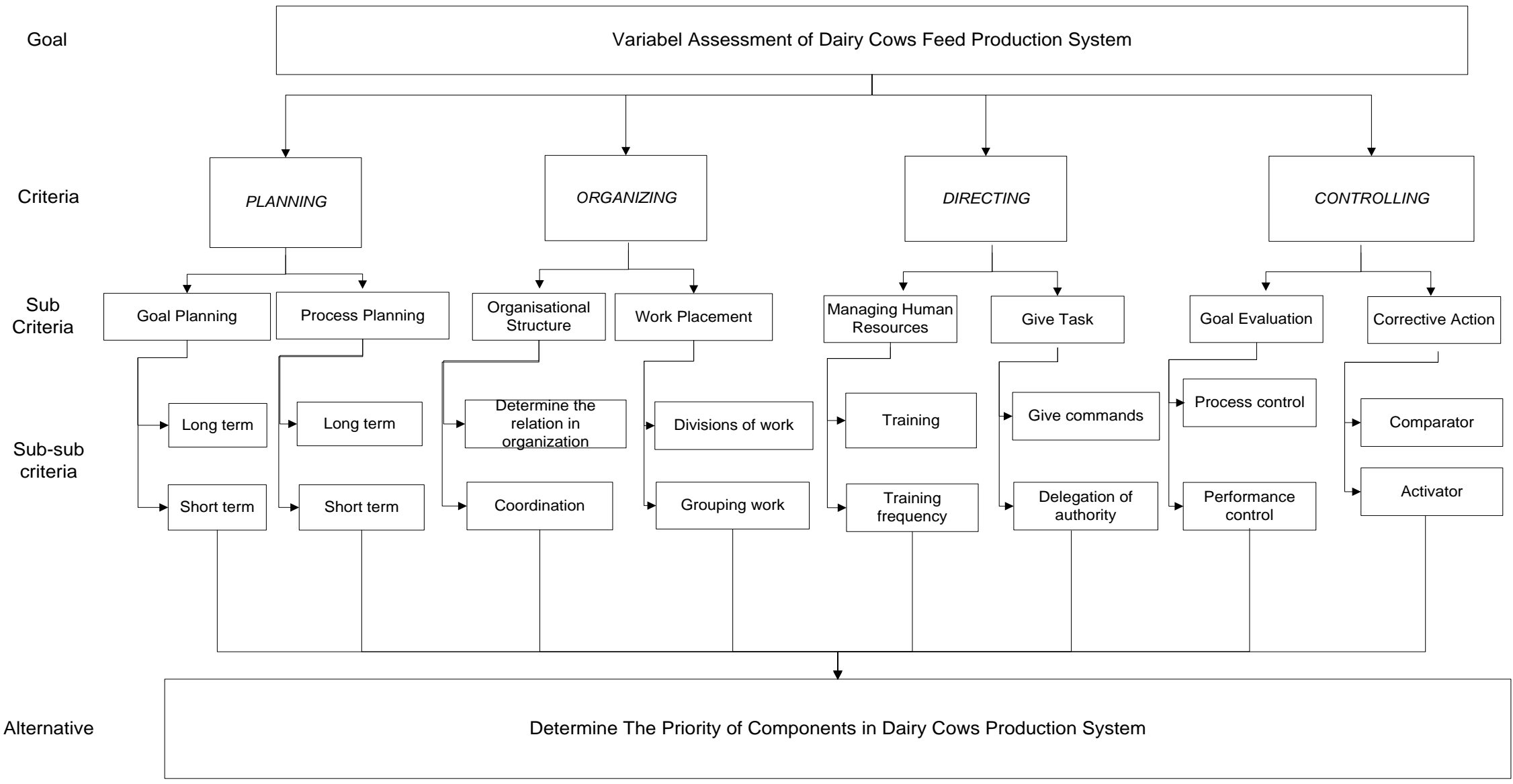

Figure 2. Hierarchical Representation of Each Management Criteria of Dairy Cows Feed Production System 
12.

$$
\mathrm{V}\left(\mathrm{M} \geq \mathrm{M}_{\mathrm{k}}\right)=\min \mathrm{V}(\mathrm{M} \geq \mathrm{Mi}), \mathrm{i}=1,2, . . \mathrm{k}
$$

Determining the value of weight vector and value of normalization

$d^{\prime}(A i)=\min V(S i \geq S k)$ for $\mathrm{k}=1,2, \ldots, \mathrm{n}: \mathrm{k} \neq i$, then the weight vector is $w^{\prime}=\left(d^{\prime}(A i), d^{\prime}(A 2), \ldots, d^{\prime}(A n)\right)^{T}$ where $A i(I=1,2, \ldots, n)$ is the $n$ elements $W\left(d(A 1), d(A 2), \ldots,(d(A n))^{T}\right.$

13. Agregation of priorities, the different level of decisions hierarchy will be reached by using the weighted sum method.

Ranking the alternatives based on the highest weight

\section{Result and Discussion}

Based on the decisions maker's opinion, the selected management criteria have been calculated using Fuzzy AHP. Figure 3 showed the global weight of management criteria. The highest weight (0.09) was long term goal planning which means these criteria is more important than others because it mostly consider about a decision which gives a huge impact. Toklu [14] mentioned that long-term goal planning helps decision makers to identify long term goals, current condition, and plan of the organization and usually done in strategic level, which can be different from one company to another [15]. Simulating different planning horizon (short term or long term) is the best approach to mention the level of detail activity. In this step, the decision makers and workers should engage in interactive discussions to identify a range of goal management (such as technological, economic, input, process, and output). The result of discussions should present the goal of management and it must be written correctly.

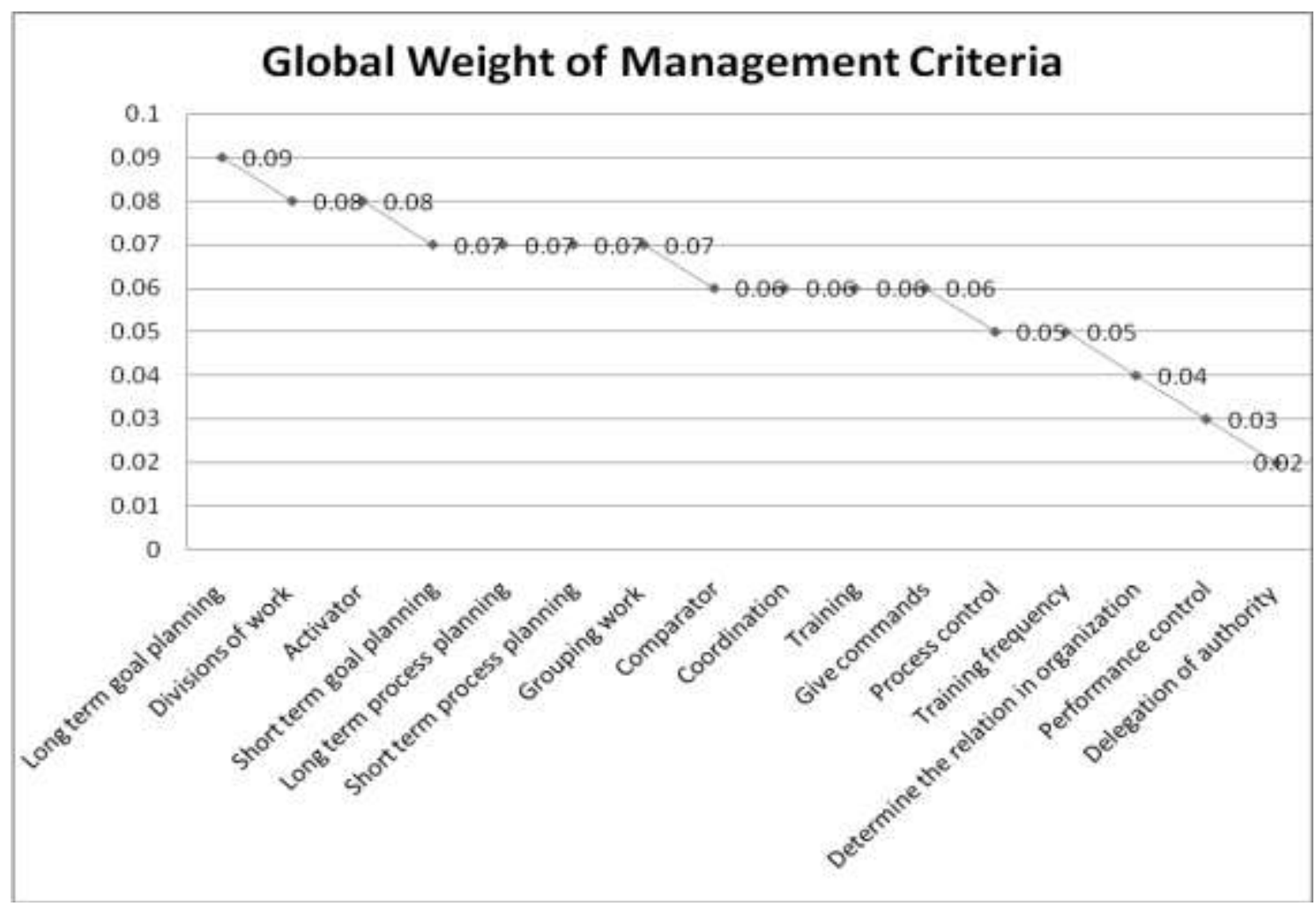

Figure 3. Global Weight of Management Criteria

The second highest weight were divisions of work placement criteria. Dividing work needs to break down the complex work into several works. Dividing work is used to divide the work into several elements and realized as job analysis, work study, and work design. Which will provide flexibility to perform these jobs and enhance high performance and productivity. The same job 
description can be combined in same group work and it would be considered as a significant element to increase performance [16]. Dividing work can show the most suitable group to complete the task to seek specific goals. The important aspect in this step is human resources diversity that refers to differences in individual characteristic (age, professional tenure, and expertise, diversity) and how that difference directly affects the process and group performance [17]. To realize these criteria into the best strategies, decision makers can build a heterogeneous team work include workers with different backgrounds to different functional works. It would give a possibility to push the superior capabilities in managing their work.

The third highest criteria were an activator. The activator is a precede condition or stimulus for certain behavior that can describe as a corrective action to return the unexpected system. It is needed to control and evaluate the system and the result is good enough or not. These criteria are applied to fulfill a control function in the managerial aspect which monitoring organizational, process performance, and human resource performance [18], [19]. Basically, control function has become an important instrument for the correct operation and preventing deviations. It's important to do to reach the best results in every production and the goal of the production system can achieve correctly.

These thirteen remaining criteria can follow up strategies. It starts form short term goal planning (0.07), long term process planning (0.07), short term process planning (0.07), and grouping work $(0.07)$ which has the same weight and lower than long term goal planning The decision makers create an effective planning by including all three remaining criteria as a follow up step. It can conclude that used of this sub-sub criteria should be the best action in the production activity planning. Then, decision makers can do some activities like comparator (0.06), coordination (0.06), training (0.06) that can be improving skills, attitude, and knowledge of human resources in order to direct them because human resources is not only a part of the production process, they also can be the key of successful production by defining and directing the process [20], give commands $(0.06)$ because the decision makers still have to direct the human resources in order to make sure the production system performance.

Next, process control $(0.05)$ and training frequency $(0.05)$, determine the relation in the organization (0.04) which can be an element to develop human resources involvement which encourages commitment and cooperation, performance control (0.03), and delegation authority (0.02). Delegation authority has lower weight because the education of human resources may give high diversities, but without supervision and direction of professional tenure will decrease the performance of the production. Based on this result, the improvement step for the performance of the dairy cows feeds production system can be seen in Figure 4. 


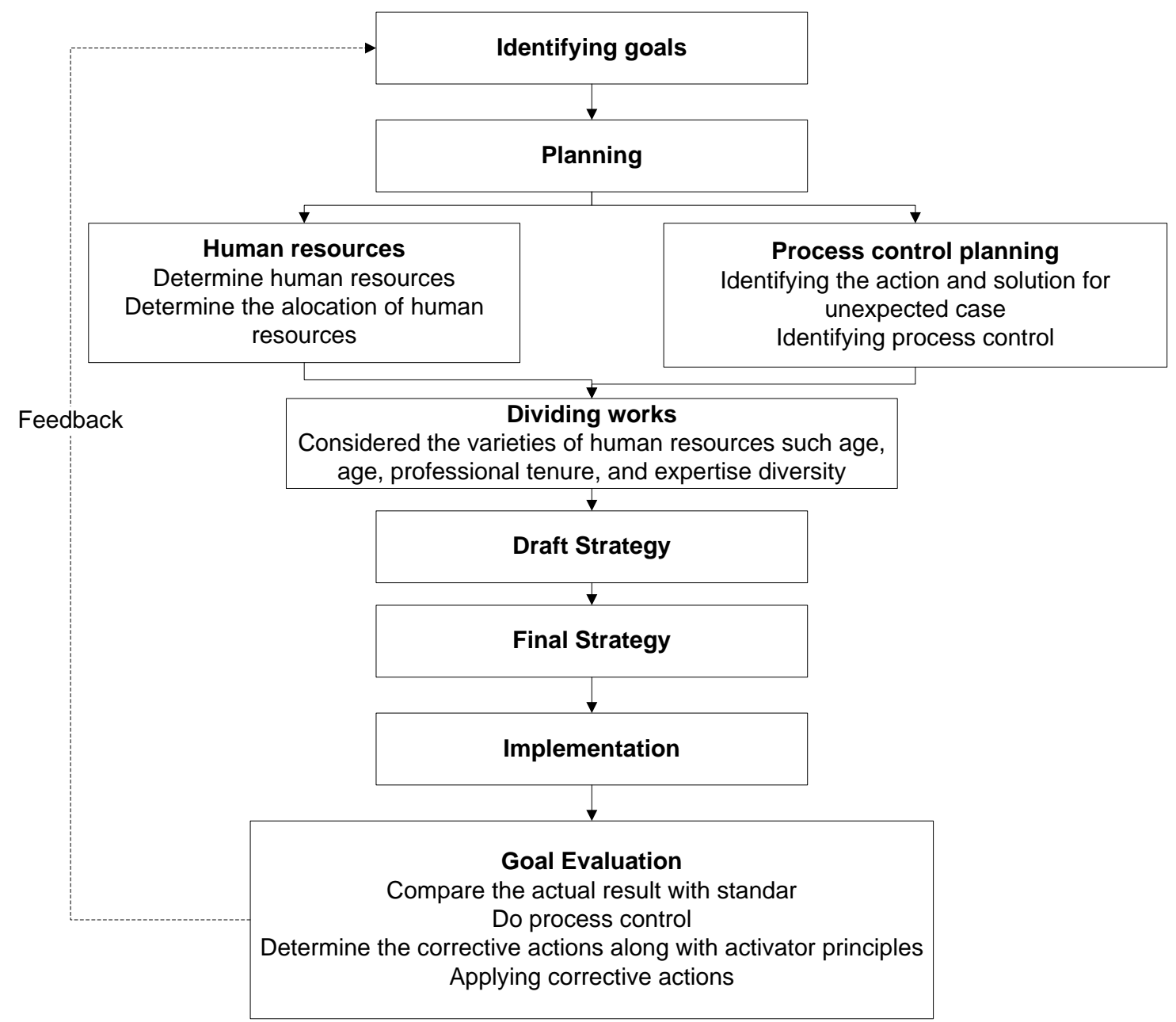

Figure 4. Improvement Step for The Performance of The Dairy Cows Feed Production System

\section{Conclusion}

The study concluded that improvement step for the performance of the dairy cows feed production system can be build by using three prioritized management criteria such goal planning from planning criteria, the division of work from organizing criteria, and activator from controlling criteria. In the future study, will be good to analyze the technical, technological, and economic aspect to examine how these criteria can affect the performance of the feed production system.

\section{References}

[1] D. Peternakan, "// Dinas Peternakan Provinsi Jawa Timur - Dinas Peternakan Propinsi Jawa Timur //," Dinas Peternakan Jawa Timur. 2013.

[2] E. Wina, Y. Widiawaty, B. Tangendjaja, and S. Iwr, "Supplementation of Calcium-Fatty Acid to Increase Milk Production and Performance of Lactating Dairy Cow," pp. 287-293, 2014.

[3] A. Baghdadi, R. A. Halim, A. Ghasemzadeh, M. Ebrahimi, R. Othman, and M. M. Yusof, "Effect of intercropping of corn and soybean on dry matter yield and nutritive value of forage corn," Legume Research, vol. 39, no. 6, pp. 976-981, 2016.

[4] Badan Pusat Statistik, "Badan Pusat Statistik." p. 1, 2017.

[5] M. Morantes, R. Dios-Palomares, M. E. Peña, J. Rivas, J. Perea, and A. García-Martínez, "Management and productivity of dairy sheep production systems in Castilla-La Mancha, Spain," Small Ruminant Research, vol. 149, pp. 62-72, 2017.

[6] E. Pe, "Management functions and productivity in dual-purpose cattle systems in Venezuela . An index-based study," no. January, 2014.

[7] D. Chatterjee, "A Study on The Comparison of AHP And Fuzzy AHP Evaluations of Private 
Technical Institutions in India," no. 1, pp. 283-291, 2013.

[8] D. E. and F. E., "A Fuzzy AHP Model for Selection of University Academic Staff," International Journal of Computer Applications, vol. 141, no. 1, pp. 19-26, 2016.

[9] H.-T. Nguyen, S. Z. Md Dawal, Y. Nukman, H. Aoyama, and K. Case, "An Integrated Approach of Fuzzy Linguistic Preference Based AHP and Fuzzy COPRAS for Machine Tool Evaluation," Plos One, vol. 10, no. 9, p. e0133599, 2015.

[10] H. M. M. M. Jayawickrama, A. K. Kulatunga, and S. Mathavan, "Fuzzy AHP based Plant Sustainability Evaluation Method," Procedia Manufacturing, vol. 8, no. October 2016, pp. 571-578, 2017.

[11] M. B. Javanbarg, C. Scawthorn, J. Kiyono, and B. Shahbodaghkhan, "Fuzzy AHP-based multicriteria decision making systems using particle swarm optimization," Expert Systems with Applications, vol. 39, no. 1, pp. 960-966, 2012.

[12] H. R. Mirzaei, E. Shahraki, M. Tavakoli, and M. Rojuee, "Planning New Management Approach for Milk Production Using the SWOT and the Fuzzy AHP Model ( A case study in the Sistan and Baloochestan province )," vol. 4, no. 7, pp. 1447-1461, 2013.

[13] M. Modak, K. Pathak, and K. K. Ghosh, "Performance evaluation of outsourcing decision using a BSC and Fuzzy AHP approach: A case of the Indian coal mining organization," Resources Policy, vol. 52, no. March, pp. 181-191, 2017.

[14] M. Cengiz Toklu, M. B. Erdem, and H. Taşkın, "A fuzzy sequential model for realization of strategic planning in manufacturing firms," Computers and Industrial Engineering, vol. 102, pp. 512-519, 2016.

[15] M. Bouchard, S. D’Amours, M. Rönnqvist, R. Azouzi, and E. Gunn, "Integrated optimization of strategic and tactical planning decisions in forestry," European Journal of Operational Research, vol. 259, no. 3, pp. 1132-1143, 2017.

[16] L. Lobanova and I. Ozolina-Ozola, "Comparative Evaluation of the Practical Areas of Human Resource Management in Lithuania and Latvia," Procedia - Social and Behavioral Sciences, vol. 110, pp. 607-616, 2014.

[17] C. M. Lu, S. J. Chen, P. C. Huang, and J. C. Chien, "Effect of diversity on human resource management and organizational performance," Journal of Business Research, vol. 68, no. 4, pp. 857-861, 2015.

[18] M. Schraeder, D. R. Self, M. H. Jordan, and R. Portis, "The Functions of Management as Mechanisms for Fostering Interpersonal Trust," Advances in Business Research, vol. 5, pp. 50-62, 2014.

[19] N. D. Retnani and D. Ardyanto, "Analisis Pengaruh Activator dan Consequence terhadap Safe Behaviour pada Tenaga Kerja di PT. Pupuk Kalimantan Timur," The Indonesian Journal of Occupational Safety and Health, vol. 2, pp. 119-129, 2013.

[20] M. Čech, W. Yao, A. Samolejová, J. Li, and P. Wicher, "Human Resource Management in Chinese manufacturing companies," Perspectives in Science, vol. 7, pp. 6-9, 2016. 